\title{
sciendo
}

10.2478/ewcp-2019-0008

\section{$I$ vs. We. First Person Personal Pronouns in Political Speeches}

\author{
ILINA-MIHAELA STĂNCULETE \\ West University of Timişoara, Romania
}

\begin{abstract}
The present article reports on a case study that focuses, comparatively, on the extent to which Romania's Prime Minister Adrian Năstase and UK's Prime Minister Tony Blair reveal their intentions and thoughts in their investment speeches, by the use of the personal pronouns $I$ and we. The number of occurrences of each of the two first person pronouns and the way in which they are used will be considered in an analysis that is both quantitative and qualitative. The overall aim of the comparative approach is to highlight how democracy is seen in the cases scrutinized, based on the activation by the speakers of the principle of cooperation in oral communication.
\end{abstract}

Keywords: cooperative principle, political speeches, oral communication, personal pronouns, power relations

\section{Personal Pronouns in Political Speeches}

Generally speaking, pronouns used in political speeches have the role of positioning the speaker relative to the addressees (as an individual separate from a group, a member of a collectivity, a person sharing the same views as the addressee's or having opinions divergent from his/hers). Sometimes, however, "the 
choice of a pronoun clearly violates a group norm and perhaps also the customary practice of the speaker. Then, the meaning of the act will be sought in some attitude or emotion of the speaker" (Brown and Gillman 272).

Furthermore, "politicians and their political activities frequently rely on language usage for communicative and persuasive reasons. So, language is seen as central to their verbal exchange activities when interacting with people for achieving their political aims" (Toska and Bello 272). Moreover, "pronouns, especially the first-person plural (we, us, our), can be used to induce interpreters to conceptualize group identity, coalitions, parties and the like, either as insiders or outsiders" (Chilton and Schäffner 30). Therefore, "the particular identities that politicians construct with pronouns include the identities of 'selves' as individuals, as well as 'selves' as members of collectives, including the politician's own political party" (Bramley 1). At the same time, the "contextual features, particularly those such as socially defined role, location, timing, are pivotal in the definition of political discourse" (Chilton and Schäffner 16).

In political speeches, personal pronouns have various functions. One of these "has been defined in terms of pronouns" capacity to act as a means of expressing different social relations. The most well-known of these is the account of the pronouns of power and solidarity by Brown and Gilman (1960) which shows how social hierarchy is reflected in the use of the pronouns" (qtd. in Bramley 14). Alternatively, "one person may be said to have power over another in the degree that he is able to control the behavior of the other" (Brown and Gilman 254). However, "power is a relationship between at least two persons, and it is nonreciprocal in the sense that both cannot have power in the same area of behavior" (Brown and Gilman 254).

Secondly, pronouns are considered "a flexible resource for constructing social categories" (Bramley 15), for shaping the speaker's identity so as to place him/her in the foreground or, on the contrary, to leave him/her in the (sometimes more secure) background. In other words, "the way people use pronouns, 
especially addressing recipients, has implications for the relationship between people and the way they are positioned in discourse" (Gyuró 25).

\section{Corpus}

The corpus used for the present analysis consists of two political speeches delivered by two politicians, in their capacity as Prime Ministers: one delivered by Romania's Prime Minister, Adrian Năstase, and the other delivered by UK's Prime Minister, Tony Blair. The former was retrieved from the official website of the Romanian Government and could be found in full at the following link: http://arhiva.gov.ro/interviu_11a5007.html (December 21 ${ }^{\text {st }}$ 2000). This speech was delivered during a TV debate to which the Prime Minister was invited immediately after winning the elections. The dialogue is conducted by a moderator who asks the Prime Minister relevant questions about the governance program, while he is offering his answers.

On the other hand, the speech of UK's Prime Minister, Tony Blair, could be found in full at the following link: http://www.britishpoliticalspeech.org/speech-

archive.htm?speech=203 (May $1^{\text {st }} 1997$ ). It is a conference speech, of a non-dialogic nature, this time, in which the Prime Minister presents his governance program, insisting on the ways of achieving the goals he set for his time in office.

The justification of the choice of the two materials is based on temporal considerations, as the two Prime Ministers filled their respective positions in approximately the same period of time (in Romania, however, elections take place more often than in other countries, so the Romanian Prime Ministers' mandates are shorter). The difference in form derives from the fact that similar formats in which the two Prime Ministers presented their programs were not available.

The overall interest I have taken in carrying out this analysis was in finding out how democracy is referred to/pictured, linguistically speaking, in each of the countries represented by the 
two politicians, in approximately the same period of time, by analysing the usage of the personal pronouns $I$ and we. This is the starting point in deciding, at a narrower level, how each of the two politicians is placing himself in relation to the society in their respective countries.

The analysis is both qualitative and quantitative. I am interested in finding the number of occurrences (frequency) of the first-person personal pronouns in each of the two materials and how these pronouns are used and in what way they contribute to shaping the concept of democracy. The result will reveal if the citizens lead the country through their elected representatives and if their rights are respected. At the same time, it would be of interest to see how the two Prime Ministers manage certain situations and to find out if they picture themselves as single individuals or as part of a community that includes both their government team and the citizens in each of the two countries.

The reason why the personal pronoun $I$ and we were chosen is the attempt to reveal which speaker each of the two Prime Ministers identifies with and, at a more general level, to reflect the impact of a political speech on the audience.

\section{Analysis Background and Design}

One of the most important events in the modern history of Romania is considered to be the 1989 Revolution that led to the collapse of the communist regime. It is known that,

immediately after the Revolution, the National Salvation Front (NSF) was formed. The newly established organization announced its commitment to democratic principles including the multiparty system and the need to organize free elections as soon as possible, while claiming to represent a decisive break with the detested Communist regime. The NSF's announcement of the transition to a pluralist system was then welcomed and trusted. (Frenţiu and Frățilă 137) 
Related to Romania's Prime Minister, Mr. Adrian Năstase, the time span that is referred to in this article is the period between 2000 and 2004, 11 years after the collapse of the communist regime, presumably time enough for democracy to have grown strong roots in Romania. The UK's Prime Minister mandate lasted between 1997 and 2007. It represents an interval when the Labour Party won the elections for the first time in 18 years.

In the case of the UK, the transition to democracy took place much earlier in comparison with Romania. Moreover, in the UK, the Prime Minister seems to have more power than his Romanian counterpart and his role is decisive in coordinating the administration of the country.

\section{The Grammatical Category of Pronouns}

Firstly, "the pronoun 'I' is used to construct a favourable image of the interviewee as an individual and is integrally related to how a politician does 'being a good politician'" (Bramley 259). Moreover, "Benveniste (1971: 218) eloquently said: "I' is the 'reality of the discourse' and 'I' signifies 'the person who is uttering the present instance of the discourse containing I"" (qtd. in Bramley 27). On the other hand, "the first-person plural personal pronoun "indicates inclusion and exclusion according to the intention of the speaker" (Gyuró 27). Furthermore, "when a politician belongs to a political party that is in opposition to another party, we is used to create an 'us and them' dichotomy between the two parties. Conversely, we can be used to paint a picture of the political party as a united team" (Bramley 24).

To sum up, "personal pronouns play an important role in negotiating social status in interaction. In other words, personal pronouns may perform not only a person deictic function, but also a social deictic function in discourse" (Wen Lin 476). Additionally, "politicians make use of pronouns to set forth their ideological views on specific issues" (Wen Lin 477). This particular morphological class has the role "to get hearers involved in their argument through making use of the pronoun we to include them" 
(Wen Lin 477); alternatively, "both the politician and subject matter may weaken the hearer's own independent thinking, which makes hearers more receptive" (Wen Lin 477). So, it is obvious that "pronoun selection is able to reveal how close or distant the speaker is to the topic under discussion or to the participants involved" (Wen Lin 477).

Most of these theoretical considerations will serve as background for the analysis in what follows. Before proceeding, one remark is felt necessary concerning the peculiar use of the personal pronoun in subject position in Romanian and English. Thus, in Romanian, it may not be expressed in the surface structure of a clause, but only understood from the context: e.g. Vă dau un exemplu / 0 give you an example - the personal pronoun $I$ is not expressed, but understood from the context and made clear by the form of the verb (i.e. its ending) that serves as the predicate of the clause. This is not to say that the pronoun cannot appear at all in the surface structure, but its mention would create the impression of unnaturalness in Romanian. In English, it is absolutely necessary for the subject to be expressed in the surface structure of a clause: "I will give you an example." - the personal pronoun $\boldsymbol{I}$ is always expressed.

\section{Results of the Analysis}

\subsection{Romania’s Prime Minister's Speech}

Firstly, in the case of Romania's Prime Minister, Adrian Năstase, the personal pronoun $I$ is used $\mathbf{8 8}$ times, while the personal pronoun $w e$ is used 60 times. It can be easily noticed that the personal pronoun $I$ is more often used in his speech. As a consequence, one may rightfully presume that, by foregrounding himself by this frequent use of the first person singular personal pronoun, the Prime Minister assumes the entire governmental responsibility, and he signals the fact that he considers his role in governing the country to be decisive. 
The personal pronoun $I$ is more often used when the Prime Minister speaks about his duties. Thus, he shows that he assumes the entire governmental responsibility. To exemplify this kind of usage, the following lines are illustrative:

(1) Eu cred că am o responsabilitate - este şi o şansă dar, în egală măsură un risc - mi le asum şi consider că avem datoria cu toţii să lucrăm pentru că, în mod categoric, nu este vorba de o miză a partidului, sau a acestei echipe guvernamentale. Este o miză a tuturor şi de aceea am încercat, pe cât posibil să implic în echipa guvernamentală şi reprezentanţi ai societăţii civile, şi reprezentanţi ai asociaţiilor profesionale.

[ $\boldsymbol{I}$ believe $\boldsymbol{I}$ have a responsibility - it is a chance, but also a risk - I take them and $\boldsymbol{I}$ think we all have the duty to work because it is definitely not a stake of the party or of this governmental team. It is a stake for all of us and that is why $\boldsymbol{I}$ have tried as much as possible to involve representatives of the civil society and of professional associations in the governmental team.]

(2) Am considerat necesar să fie şi oameni noi, care să vină cu tinereţe, cu dinamism şi cu idei proaspete în zona Guvernului.

[I considered it necessary to have new people around, who would bring their youth, dynamism and fresh ideas in the Government.]

(3) Pe de altă parte, am considerat că este momentul pentru o mai bună reprezentare în Guvern a celor din Transilvania. Nu aş putea spune, însă, că acest criteriu a fost cel care m-a determinat să aleg pe unii dintre miniştri. Este vorba de oameni de mare calitate pe care i-am cunoscut în ultimii ani.

[On the other hand, $\boldsymbol{I}$ thought it was time for better representation in the Government of those from Transylvania. But $\boldsymbol{I}$ could not say that this criterion was the one that made me choose some of the ministers. They are high quality people whom $\boldsymbol{I}$ have met in recent years.]

The Prime Minister also uses the personal pronoun $I$ when his statements are meant to highlight wrong doings of his political opponents, as in the fragment below: 
(4) Aş spune pentru că în perioada aceea dl. preşedinte Constantinescu mai mult s-a plimbat prin străinătate şi nu a avut un rol în ceea ce priveşte guvernarea.

[I would say it was because during that time, President Constantinescu spent more time abroad and did not play a role in governance.]

He also uses the personal pronoun $I$ repeatedly when speaking about why he took on the tasks associated with being Prime Minister. In this particular instance, he may want to convey that he is very open, very sincere and responsible in his new administrative capacity:

(5) $\mathrm{Da}$, am acceptat cu greutate pentru că sunt foarte conştient de responsabilitatea acestei echipe guvernamentale. Mi-am pus întrebări în ce măsură aceasta este cea mai bună formulă guvernamentală şi am ajuns la concluzia că în nici un caz o lipsă de implicare nu ar fi răspunsul potrivit nici pentru colegii mei, nici pentru populaţie, care aşteaptă de la noi o acţiune responsabilă.

[Yes, $\boldsymbol{I}$ have accepted with difficulty because $\boldsymbol{I}$ am very much aware of the responsibility of this government team. $\boldsymbol{I}$ have wondered to what extent this is the best government formula, and $\boldsymbol{I}$ have come to the conclusion that, under no circumstances would the lack of involvement be the right answer either for my colleagues, or for the citizens who are waiting for responsible action from us.]

Finally, the Prime Minister employs the personal pronoun $I$ when referring to the communist era, which he opposes, and when trying to underline the idea of privatization, which he supports:

(6) Vreau să vă spun că nu am complexe ideologice în legătură cu privatizarea. Voi fi atacat că nu fac suficiente kilograme de privatizare şi că asta înseamnă că sunt un fost comunist care nu a înţeles cum este cu proprietatea privată şi cu capitalismul. Vreau să vă spun că nu am complexe de genul acesta.

[ $\boldsymbol{I}$ want to tell you that $\boldsymbol{I}$ do not have ideological complexes in connection with the privatization. $\boldsymbol{I}$ will be attacked for not making enough kilos of privatization, and that means that $\boldsymbol{I}$ am a former communist who did not understand how things work with private 
property and capitalism. $\boldsymbol{I}$ want to tell you that $\boldsymbol{I}$ do not have any complex of the kind.]

The Prime Minister uses the pronoun we when talking about the setting up of his governance program. This choice may indicate that he is, after all, willing to share some of his responsibility with the members of his team. From this perspective, the following lines may be illustrative:

(7) Pe de o parte, avem programul acesta de guvernare dar, pe de altă parte, în luna ianuarie, vom lucra la acest program pe termen mai lung - probabil pe 10 ani - în încercarea de a prezenta ceea ce considerăm important, pornind sigur, şi de la strategia pe termen mediu transmisă la Bruxelles, adăugând elemente pe care le considerăm esenţiale din experienţa ultimilor ani.

[On the one hand, we have this governance program, but on the other hand, in January, we will be working on this long-term program perhaps for 10 years - in the attempt to present what we consider important, surely starting from the medium-term strategy forwarded to Brussels, adding elements that we consider essential based on our experience during the past few years.]

(8) Noi încercăm să combinăm elementele de reformă, de restructurare economică, care vor presupune, fără îndoială, şi şomaj, pierderi de locuri de muncă, dar, pe de altă parte, dorim să şi creăm locuri de muncă prin întreprinderi mici şi mijlocii.

[We are trying to combine the elements of reform, economic restructuring, which will undoubtedly involve unemployment, job losses, but, on the other hand, we want to create jobs through small and medium enterprises.]

(9) Sunt o mulţime de alte lucruri pe care le urmărim: vom reduce TVAul, spre exemplu, la câteva produse alimentare de bază. În prima parte a anului viitor, vom reduce TVA-ul la energie.

[There are a lot of other things we are pursuing: we will reduce the VAT, for example, for some basic food products. In the first part of next year, we will reduce the VAT on energy.]

\subsection{UK's Prime Minister's Speech}


In the case of UK's Prime Minister, Tony Blair, the personal pronoun $I$ is used 64 times, while the personal pronoun we is used 137 times, almost twice as often. This choice supports the idea that the British Prime Minister, unlike the Romanian one, foregrounds himself as the member of a collectivity in which his team and the citizens of the country are included. This further emphasizes that he respects the principle of democracy which is based on the active participation of the citizens in the political life.

Worth mentioning is the fact that the entire speech is constructed on a positive note. The Prime Minister insists on revealing the strengths of the society. Most of the times, he chooses not to speak about the weaknesses of the administration he has just become the head of, without, however, forgetting the aspects that could be improved. In many cases, by using the personal pronoun $I$, the Prime Minister only makes promises. Even if it may be possible that the members of his team agree with him, he does not refer to them directly or indirectly, as members of the same team. The reason why he chooses this kind of approach may be his willingness to speak for himself, not for the others. To exemplify, the following statements are illustrative:

(10) And I repeat the promise I made at the election, that over the lifetime of this parliament, we will reverse the Tory policy [...].

(11) And $\boldsymbol{I}$ will not rest until that country is gone and all our children live in a Britain where no child goes hungry, the young are employed, and the old are cherished and valued to the end of their days.

Moreover, by using the personal pronoun $I$ in some statements, the Prime Minister wants to highlight his ambitious goals and the assumption that he is in the position to meet them. This is what one may understand from examples such as (12) and (13):

(12) We have never won two full consecutives terms of office. Never. That is one more record $\boldsymbol{I}$ want to break.

(13) But $I$ want to do more than keep our promises. $I$ sense the British people demand more of us, too. 
Furthermore, by using the personal pronoun $I$, in some cases, the Prime Minister, though a team player in general, expresses his own desires, apart from those of his team. In other words, he tries to show his own identity in the ideas, concerns or opinions put forth. See, for example, quotations (14) to (16):

(14) It's pretty simple the type of country $I$ want. It's a country where our children are proud and happy to grow up in, feeling good not just about themselves, but about the community around them.

(15) And $\boldsymbol{I}$ tell you. $\boldsymbol{I}$ will never countenance an NHS that departs from its fundamental principle of health care based on need not wealth.

(16) $I$ want reform.

Second, the Prime Minister uses the personal pronoun we when he speaks about the strengths of his party which won the elections. In such instances, the opposite of the above becomes more evident, i.e. the fact that Blair knows when to push the team player button:

(17) We won because we are New Labour, because we had the courage to change ourselves, and the discipline to take hard decisions, whilst remaining united. The lessons we learned in Opposition we carry on applying in Government. The moment we stop that is the moment we will stop being government.

The personal pronoun we is often resorted to by Blair when he speaks about the strengths of the nation he represents. The role of this kind of approach is, most probably, to get close to the citizens in order to gain their confidence, all the more so as in the majority of cases, this inclusive use of the first-person plural pronoun is made with reference to outstanding characteristics of the British or to their remarkable deeds. To exemplify, the following lines are representative:

(18) We are one of the great innovative peoples.

(19) Change is in the blood and bones of the British, we are by our nature and tradition innovators, adventurers, pioneers. 
(20) Even today, we lead the world, in design, pharmaceuticals, financial services, telecommunications.

(21) We have the world's first language.

The Prime Minister also uses the personal pronoun we to refer to past achievements of the party he represents. In this way, he signals the fact that he is not solely to praise for what has been achieved, but rather that it is the collectivity whose merits need to be brought into the limelight. This is what one may understand from examples such as (22) to (29), built on a repetitive (and therefore, emphatic) structure - this is what we have undertaken to do - this is exactly what we have done (if not more, in a positive direction):

(22) We said we would get more money into schools and hospitals. We have -2.2 billion more than Tories planned to spend next year.

(23) We said we'd sign the Social Chapter. We did.

(24) We said we'd set up a Low Pay Commission. We have, and the national minimum wage is on its way.

(25) We said we'd legislate to release the money from selling council homes in order to house the homeless. We've done it.

(26) We said we'd cut class sizes, by scrapping the Assisted Places Scheme. The law to do it has been passed.

(27) We said we'd reform the Lottery to address the people's priorities. We have, and today more proposals on how we'll reform it further and get more money to more local projects, the length and breadth of Britain, preparing for the millennium.

(28) $\boldsymbol{W} \boldsymbol{e}$ said we'd cut VAT on fuel. We have.

(29) We never said we'd cut corporation tax. But we did anyway, to the lowest level it's ever been.

After all, we always gives citizens the sense of belonging to a community, and the British Prime Minister knows this pretty well, when he takes advantage of the use of this pronoun in examples such as (30): 
(30) Today I say to the British people: the chains of mediocrity have broken, the tired days are behind us, we are free to excel once more. $\boldsymbol{W e}$ are free to build that model 21 st century nation, to become that beacon to the world.

Inclusive we is employed for highlighting future plans as well. It is used, for instance, to highlight the fact that education is an essential issue not only for the citizens, but also for the whole political class:

(31) We are setting a new target of $£ 2$ billion for this parliament for our school repairs and equipment programme.

\section{Conclusion}

Based on the use of the personal pronouns $I$ and we discussed so far, some conclusions may be drawn concerning how the two Prime Ministers reveal their own identities, and the way in which they understand the principles of democracy. The preference for the usage of the personal pronouns depends on their perception of democracy: the predominant usage of the personal pronoun $I$ means assumption of the entire responsibility and desire to place one's own personality and ideas in the foreground; the frequent usage of the personal pronoun we, on the other hand, places emphasis on the idea of a 'team' which much better matches that of democracy.

Through the predominant usage of the pronoun $I$, the Romanian Prime Minister proves that he does not totally resonate with the idea of democracy. By contrast, in the case of the UK Prime Minister, the most frequently used pronoun is the plural we, which denotes the fact that he is more strongly attached to the idea of democracy, and he tries, as much as possible, to respect it through consolidating the concept of the 'team' in which everyone has the duty to perform and through considering himself a part of it.

Thus, the use of the first-person personal pronouns may be said to be significant beyond what they can tell about the person who employs them, to what it can actually say about the society as a whole. 


\section{Works Cited}

Bramley, Nicolette Ruth. Pronouns of Politics: The Use of Pronouns in the Construction of 'Self' and 'Other' in Political Interviews. 2001. Australian National University, PhD. dissertation. Web. 2 Apr. 2019.

Brown, Roger, and Albert Gilman. "The Pronouns of Power and Solidarity." Readings in the Sociology of Language. Ed. J. A. Fishman. The Hague: Mouton, 1968. Print.

Chilton, Paul A., and Christine Schäffner, eds. Politics as Text and Talk: Analytic Approaches to Political Discourse. Amsterdam: Benjamins, 2002. Print.

Frenţiu, Luminiţa, and Loredana Frățilă. "Promises and Pie-crusts are Made to be Broken." BAS: British and American Studies 4.1 (1999): 132-143. Print.

Gyuró, Monika. "Construction of National Identity: Power in Acceptance Speeches." Discourse and Interaction. 8 Jan. 2015. (2015): 21-36. Web. 2 Apr. 2019.

Toska, Bledar, and Vilma Bello. "I as a Powerful Means of Selfrepresentation and Political Identity Construction in Trump's Discourse during 2016 Presidential Debates." Redefining Community in Intercultural Context 7.1 (2018): 272-276. Print. Wen Lin, Cheng. "The Study of Political Language: A Brief Overview of Recent Research." Chia Nan Annual Bulletin 37 (2011): 471-485. Web. 2 Apr. 2019.

"Interview Adrian Năstase at Marius Tucă Show." 21 Dec. 2000. Web. 2 Apr. 2019.

"Leader's Speech, Brighton 1997, Tony Blair (Labour)." BritishPoliticalSpeech 1 May 1997. Web. 2 Apr. 2019. 